\title{
トリクロロエチレンとイソプロピルアルコールの 肝内代謝における相互作用
} ーラット灌流肝臓における実験—

\author{
王 廣増*1,*2, 高野 健人*1, 富田 和久*1, \\ 仲田 和代*1, 中村 桂子*1 \\ *1東京医科歯科大学医学部公衆衛生学教室 \\ *2現在 中華人民共和国・河北省唐山市華北煤炭医学院予防医学系毒理学教研室
}

\section{Interaction of Trichloroethylene and Isopropyl Alcohol in the Perfused Rat Liver}

\author{
WANG Guang-zeng, Takehito TAKANO, Kazuhisa TOMITA, \\ Kazuyo NAKATA and Keiko NAKAMURA \\ Department of Public Health and Environmental Science, \\ School of Medicine, Tokyo Medical and Dental University, Tokyo
}

\begin{abstract}
The interaction of trichloroethylene (TCEL) and isopropyl alcohol (IPA) was studied in the perf used rat liver. Experiments consisted of four parts; TCEL administration with or without IPA, chloral hydrate $(\mathrm{CH})$ administration with or without IPA, IPA administration with or without CH, IPA administration with or without trichloroethanol (TCE). The chemicals were administered into the perf usate of Krebs-Henseleit buffer saturated with $95 \% \mathrm{O}_{2} / 5 \% \mathrm{CO}_{2}$ in a non-recirculating circuit. Concentrations of the following three metabolites in the effluent were continuously measured by gas chromatograph and chemical methods: TCE and trichloroacetate (TCA) (metabolites of TCEL and CH), and acetone (a metabolite of IPA). Fluorescence from intracellular reduced pyridine nucleotides (NADH, NADPH) was monitored by surface fluorometry. The results showed that IPA changed the TCA/TCE ratio in the TCEL metabolism because of an increase in NADH production, and IPA oxidation was suppressed by $\mathrm{CH}$ because of an inhibitory effect of TCE on alcohol dehydrogenase. It was concluded that IPA and TCEL, both ubiquitous agents, interacted with each other in their metabolic pathways in the perfused rat liver, suggesting a new feature of a combined effect of these chemicals when they coexist.
\end{abstract}

Key words : Trichloroethylene (トリクロロエチレン), Isopropyl alcohol (イソプロピルアルコール), Chloral hydrate (抱水クロラール), Perfused rat liver (ラット灌流肝蔵), Redox state (酸化還元状態)

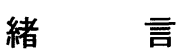

トリクロロエチレン(trichloroethylene, TCEL)は広

く使用されている有機塩素系化合物であり，また環境污 染物質としても検出されている有機溶剤である ${ }^{1)}$ 。TCEL の毒性に関する知識の普及に伴い, その使用は注意深く
} 
行われる傾向 2) にあるが，なおTCELに関するより多く の衛生学的情報が必要であると思われる。特に, 用量反 応関係や中毒症状などに関する毒性情報だけでなく，代 謝のメカニズムを明らかにする研究は, 労働者や住民の 健康を総合的淠配慮するらえで重要な基礎資料になるも のと考兄られる。

一方, イソプロピルアルコール (isopropyl alcohol, IPA) も頻用されている化学物質である ${ }^{3)}$ 。

我々は, TCELとIPAといら二種類の有機溶剤の複合 影響に興味を持ち, この二種類の化学物質のそれぞれの 代謝に及ぼす相互作用に着目し, ラットの灌流肝臓を実 験モデルとして，ひとつの実騟所見の事実を得ることを 目的として本研究を行った。

TCELの体内代謝は，多くの研究報告によって明らか にされている4〜7)。体内に吸収されたTCELは主に肝臓 においてチトロクローム $\mathrm{P}_{450}$ 系 $\left(\mathrm{P}_{450}\right)$ により, 中間代 謝産物の抱水クロラール(chloral hydrate, $\mathrm{CH}$ ) に代謝 される4)。このCHは, さらに, 生体内変換をうけ, ト リクロロ酢酸 (trichloroacetic acid, TCA), あるいは,

トリクロロエタノール(trichloroethanol, TCE) に代謝 される5)。すなわち, 抱水クロラール脱水素醳素により TCAに酸化される代謝経路と, アルコール脱水素酵素 (ADH)によってTCEに還元される代謝経路の 2 種類の 経路の存在が知られている ${ }^{4,6)}$ 。

CHがTCEに代謝される場合にはNADHが必要とされ， CHがTCAに代謝される場合にはNADが必要とされる。 したがって, TCEとTCAの産生比(TCE/TCA比) は細胞 内酸化還元状態, 特にNAD/NADH比によって変化する ことが報告されている8)。

一方, IPAも従来より肝臟においてADHによってアセ トンに代謝されることが知られている ${ }^{9,10)}$ 。また，IPA がADHによってアセトンに酸化される場合はNADが必 要とされ, NADHが産生される。そこで, TCEL代謝とIPA 代謝の相互影響を観察するためには，細胞内のNAD/NADH の変動をモニターすることが不可欠である。

この目的に合致した実験系として，我々はラット灌流 肝臓を調整し, 臓器螢光分析装置を用いて, NAD/NADH の酸化還元状態の変化をモニターし, さらに, TCELお よびIPAのそれぞれの代謝産物の産生率を測定し, 代謝 動態変化の把握を行った。

その結果, TCELとIPAはそれぞれの代謝の過程で細 胞内NAD/NADHレベルを変化させ, 相互に影響を及ぼ し合らことの一端が判明したので以下に報告する。
方法

\section{1.ラット灌流肝臓の調整}

実験動物は, Wistar 系ラット（雄, 体重200-300 g, 日本クレア)を用いた。飼育は $24^{\circ} \mathrm{C}$, 午前 6 時点燈, 午 後 6 時消燈の12時間の明暗サイクルで行い, 飼料 (CE-2, 日本クレア)と水の摂取は自由とした。20頭を一群 5 頭 とし4群にわけた。TCEL投与実験に用いたラットはTCEL を代謝するP 450 を誘導するため, フェノバルビタール (連続 4 日間, $70 \mathrm{mg} / \mathrm{kg}$ 体重, 腹腔内投与) 投与の前処 理を行った。

ラット肝臓の灌流方法は既報 ${ }^{11)}$ に準じて行った。す なわち, ペントバルビタール $(50 \mathrm{mg} / \mathrm{kg}$ 体重, 腹腔内投 与)により麻酔し, 開腹後, カニューレを門脈に挿入し, 肝臓が膨潤しないように注意して灌流を行った。流出液 は下大静脈から導いた。

灌流液は, 血液成分を含をないKrebs-Henseleit buffer を用い， $95 \% \mathrm{O}_{2}-5 \% \mathrm{CO}_{2}$ で飽和した。基質として，ま た細胞内酸化還元電位を生理的な状態に定常的に保つた め, $1.0 \mathrm{mM}$ 乳酸と0.1 $\mathrm{mM}$ ピルビン酸を使用した。灌 流温度は $31^{\circ} \mathrm{C}$, 灌流量は $30 \mathrm{ml} /$ 分とした。

酸素消費量は, 灌流液を大静脈より外気と隔絶して導 き, 電極法により測定した酸素分圧の変化値と流量値か ら算出した。

流出液は 2 分毎に採取した。

使用した試薬類は以下の市販品(特級)を用いた。TCEL おょびIPAは関東化学より, CH, TCEおよびTCAはナカ ライテスクより購入した。

\section{2. 臓器螢光分析}

灌流肝臓における還元型ピリジンヌクレオチド(PN) の螢光変化の経時的測定はすでに本誌で報告した臟器螢

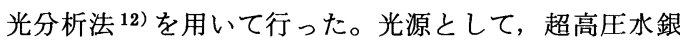
燈を用い,フィルターと石英ファイバーにより $366 \mathrm{~nm}$ の励起光を臟器表面に照射し, 還元型PNから発せられ る䖝光を, 同じく石英ファイバーとフィルターにより選 択して，光電子増倍管に導いた。同時に， $720 \mathrm{~nm}$ の近 赤外光を用いて光の反射条件を監視し補正した。

\section{3. 代謝産物の測定}

TCEとTCAの測定は，ガスクロマトグラフ(島津GC-7A， ECD)を用い，Humbert とFernandez の方法 ${ }^{13)}$ とより 測定した。IPAの代謝産物アセトンの測定は，自記分光 光度計(日立100-50)を用いて, サリチルアルデヒド定量 法 ${ }^{14)}$ によって測定した。 


\section{4. 実験条件}

実験は次の四条件について行った。i）灌流液中最終 濃度0.1 mMのTCELを24分間負荷し，途中 8 分間 $10 \mathrm{mM}$ のIPAを同時負荷。ii) 灌流液中最終濃度 $0.1 \mathrm{mM}$ の $\mathrm{CH}$ を24分間負荷し，途中 8 分間 $10 \mathrm{mM}$ のIPAを同時負荷。iii) 灌流液中最終濃度 $10 \mathrm{mM}$ のIPAを24分間負荷し, 途中 8 分間 $1.0 \mathrm{mM}$ の CHを同時負荷。iv) 灌流液中最終濃度 10 $\mathrm{mM}$ のIPAを 24 分間負荷し, 途中 8 分間を $0.1 \mathrm{mM}$ の TCE を同時負荷。

\section{5. 推計学的検討}

平均值の差の検定は， $t$-testにより行い，有意水準は $5 \%$ とした。

\section{結果}

\section{TCEL代謝に及ばすIPAの影響}

灌流肝臓に0.1mM TCELを負荷した後， $10 \mathrm{mM} \mathrm{IPA}$ を同時に負荷したときの酸素消費量, 還元型PNレベル の変化率, TCA, TCEの産生率の経時的変化を図 1 k典 型例として示した。また, TCEL単独負荷時, TCELとIPA 同時負荷時, 同時負荷終了後のTCEL単独負荷時の各プ ラトー時におけるPN変化率, TCA産生率およびTCE生 産率を表 1 に示した。

TCEL単独負荷により, 還元型PN量は減少し，投与 3 分後にほぼ一定の值に達した。また，灌流排出液中に TCEおよびTCAが認められ，TCA/TCE産生比はほぼ 8 ： 1 であった。TCELとIPA同時負荷開始後, 図 1 にみら れるように急速に還元型PN量は増加した。また, TCE 産生率むTCEL単独負荷時と比較して3.2倍まで有意に 増加した。一方, TCA産生率はIPA負荷により TCEL単 独負荷時の $55 \%$ をて有意に減少した。IPA負荷中止後, 還元型PN量は再び減少し, IPA負荷前のレベルに戻っ

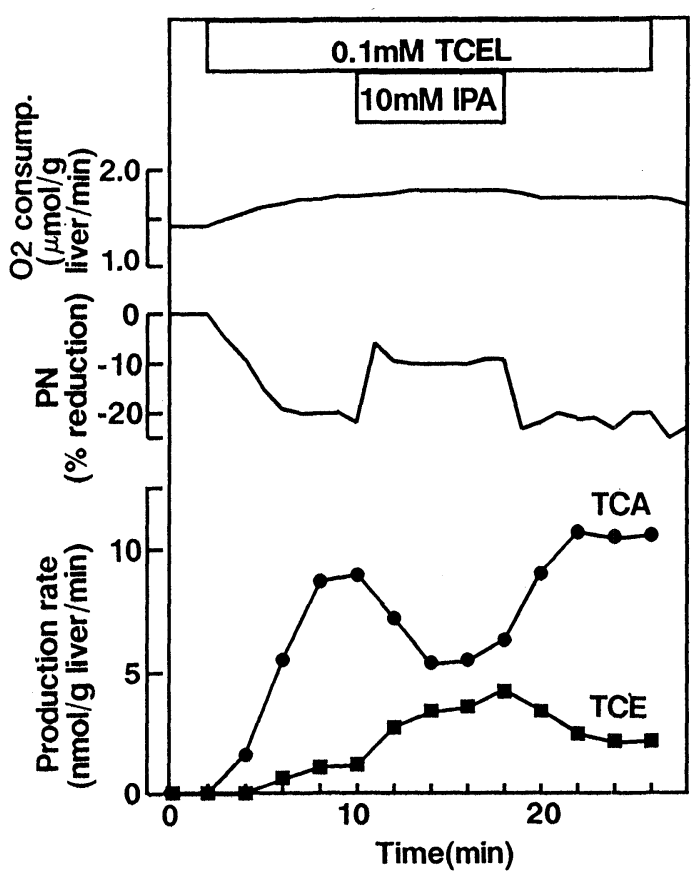

Fig. 1 Typical changes in oxygen consumption, reduced pyridine nucleotides $(\mathrm{PN})$, and production rates of trichloroethanol (TCE) and trichloroacetic acid (TCA) following administration of trichloroethylene (TCEL) with or without isopropyl alcohol (IPA) in the perfused rat liver

The redox level of PN is measured as percent reduction. In the present experiment, $100 \%$ reduction was defined as the level reached when inducing complete anoxia, and $0 \%$ reduction was defined as the stable level maintained in Krebs-Henseleit buffer with an adequate oxygen supply.

Table 1 Effect of isopropyl alcohol (IPA) on levels of reduced pyridine nucleotides (PN), production rates of trichloroethanol (TCE) and trichloroacetic acid (TCA) in the perfused rat liver during trichloroethylene (TCEL) administration

\begin{tabular}{lccc}
\hline & \multicolumn{3}{c}{$0.1 \mathrm{mM}$ TCEL } \\
\cline { 2 - 4 } & Without IPA $^{\mathrm{a}}$ & With $10 \mathrm{mM} \mathrm{IPA}^{\mathrm{c}}$ & Without IPA $^{\mathrm{b}}$ \\
\hline $\begin{array}{l}\text { Change in reduced } \\
\text { PN level (\%) }\end{array}$ & $-19.3 \pm 1.4$ & $-7.5 \pm 0.8^{\mathrm{c}}$ & $-21.0 \pm 0.5$ \\
$\begin{array}{l}\text { TCE production rate } \\
\text { (nmol/g liver/min) }\end{array}$ & $0.95 \pm 0.16$ & $3.10 \pm 0.64^{\mathrm{c}}$ & $1.68 \pm 0.27$ \\
$\begin{array}{l}\text { TCA production rate } \\
\text { (nmol/g liver/min) }\end{array}$ & $7.63 \pm 0.75$ & $4.24 \pm 1.01^{\mathrm{c}}$ & $8.06 \pm 1.23$ \\
\hline
\end{tabular}

All values are means \pm SE. $n=5$.

${ }^{a}$ Values when $0.1 \mathrm{mM}$ TCEL was administered alone before IPA administration.

${ }^{\mathrm{b}}$ Values when $0.1 \mathrm{mM}$ TCEL was administered alone after IPA administration.

c represents a statistically signif icant difference caused by IPA administration. 
た。また, TCEおよびTCA産生率も還元型PNと同様, IPA 負荷中止後にはIPA負荷前のレベルに戻った。

\section{CH代謝に及ぼすIPAの影響}

TCELの中間代謝産物であるCHの代謝に及ぼすIPAの 影響について，同じく代謝産物のTCEおよびTCAの産 生率の変化を図 2 に示した。CHを負荷した場合の還元 型PN量の減少 $(-8.72 \pm 0.57, \%, \mathrm{n}=5)$, また, IPA投 与時の還元型PN量の増加 $(2.71 \pm 1.39, \%, \mathrm{n}=5)$ が認め

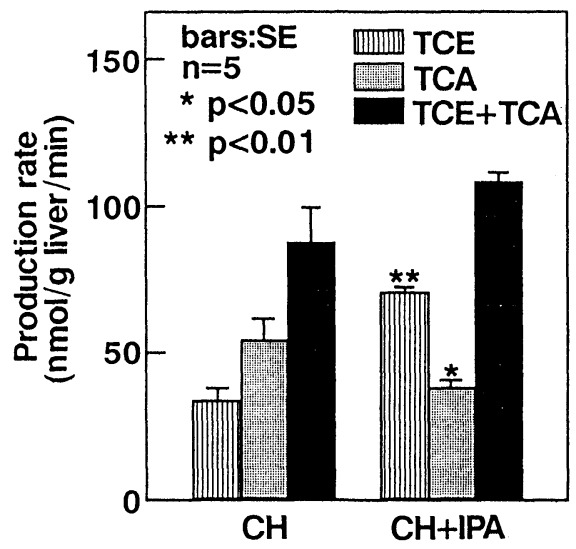

Fig. 2 Changes in trichloroethanol (TCE) and trichloroacetic acid (TCA) production rates following administration of chloral hydrate (CH) with or without isopropyl alcohol (IPA) in the perfused rat liver A significant difference from the value for $\mathrm{CH}$ alone is shown.

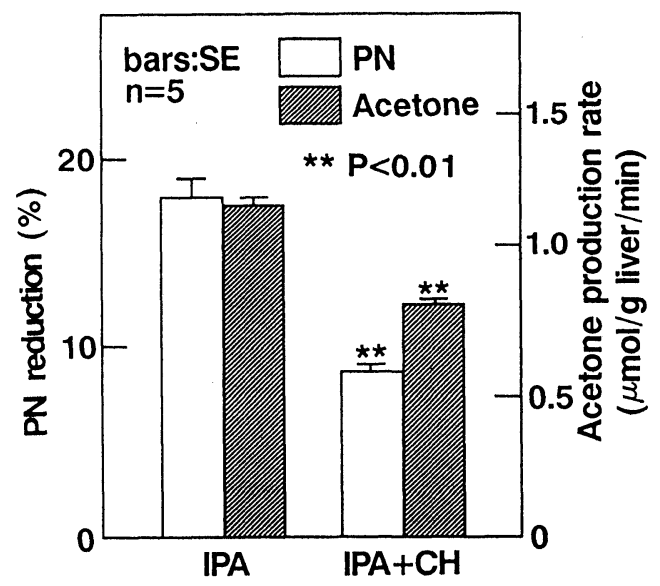

Fig. 3 Changes in the reduced pyridine nucleotide (PN) level and acetone production rate following administration of isopropyl alcohol (IPA) with or without chloral hydrate $(\mathrm{CH})$ in the perfused rat liver A significant difference from the value for IPA alone is shown.
られた。

図2にみられるように, CH単独負荷の場合, TCE, TCA 産生率はそれぞれ，33.8土4.1 nmol $/ \mathrm{g}$ liver $/ \mathrm{min}, 54.7$ $\pm 6.7 \mathrm{nmol} / \mathrm{g}$ liver/min であり, TCA産生がTCE産生を 上回っていた。

IPAを同時に負荷した場合, TCE産生率は $\mathrm{CH}$ 単独負 荷時の産生率と比べて2.1倍の有意な増加が認められた (図 2 )。一方, TCA産生率は, IPA同時負荷時には, $\mathrm{CH}$ 単独負荷時の産生率の $68 \%$ であり, 有意に減少した。IPA 同時負荷により, CHの主たる代謝産物はTCAから TCE へと変化したが, TCEと TCA産生率の合計産生率はCH 単独負荷時のそれと比べて有意差を認めなかった。

\section{IPA代謝に及ぼすCHの影響}

灌流肝藏に10mM IPAを負荷した時ならびに10mM IPA と0.1mM CHを同時負荷した時の還元型PN変化率, ア セトン産生率を図 3 に示した。IPAがアセトンに代謝さ れる過程において，アセトン産生率はCHの同時負荷に より有意に抑制されることが認められた。

\section{IPA代謝におよばすTCEの影響}

灌流肝臓に10mM IPAを負荷した時ならびに10mM IPA と0.1mM TCEを同時負荷したときのアセトン産生率を 図 4 に示した。その結果, TCEの同時負荷によりアセト ン産生率の有意な抑制(76\%)が認められた。

\section{考察}

ラット灌流肝臓に対してTCELとIPAの同時負荷をお こなった結果, TCELは肝臓において代謝され, TCAと

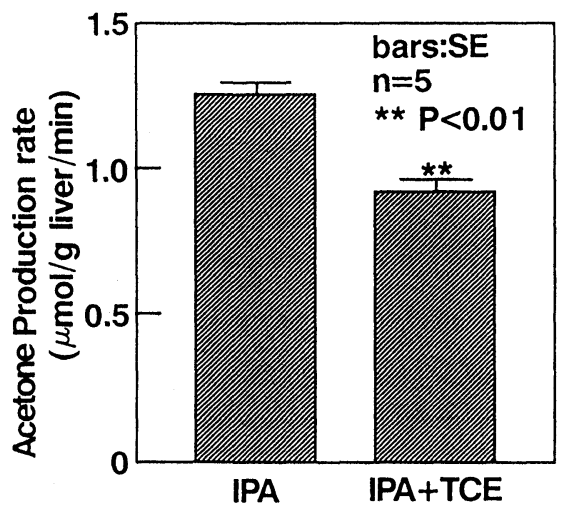

Fig. 4 Changes in the acetone production rate following administration of isopropyl alcohol (IPA) with or without trichloroethanol (TCE) in the perfused rat liver

A significant difference from the value for IPA alone is shown. 
TCEの産生をもたらし，IPAが共存することにより，TCA の産生は減少し, TCEの産生が増加することが示された。

また, 臟器䖝光分析法による肝細胞内還元型PNレベ ルの観察により, TCEL投与が還元型PNレベルを低下 させ，IPA投与は還元型PNレベルを上昇させることが 示された。

TCEL投与により還元型PNの減少は, TCELからP450 によりCHに変化する際に消費されるNADPHと， CHか らTCEに変化する際に消費されるNADHの両方の減少分 を含むものと考兄られた。TCELの中間代謝産物であるCH とIPAの同時負荷によって, 肝細胞内還元型PNレベル は，TCELとIPAの同時負荷における結果と同様の方向 への変化を示した。しかし，この場合の還元型PNの変 化は，P450によるNADPH消費を含まない变化と考兄ら れ，CHからTCEへの代謝によるNADHの消費， CHから TCAへの代謝によるNADHの産生，IPAからアセトンへ の代謝によるNADHの産生の加減の結果を示しているも のと考えられた。

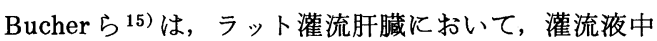
の乳酸とピルビン酸の濃度を変化させ，本実験で用いた ものと同様の藏器螢光分析法により, 還元型PNの螢光 量変化が肝細胞内の酸化還元状態(redox state)を示し ており, それが, 乳酸/ピルビン酸比 $10: 1$ 亿おいて, 生体内に打ける生理的な酸化還元状態と同様のレベルに あることを報告している。また，Kawamoto ら ${ }^{8)}$ は， 灌流肝臓に战いて, 比較的低濃度 $(0.1 \mathrm{mM})$ のCH投与 下では, 代謝産物はTCAの比率が高く, TCEの比率が 低いことを報告している。しかしながら，高濃度のCH $(1.0$ $\mathrm{mM})$ 投与によっては, 代謝産物はTCEの比率が高くな り，TCAの産生率を上回ることを同時に観察している。

これらのことを勘案すると, TCA/TCE比は, 細胞内 のNADH/NADの変化によって影響を受けやすく，容易 に変化するものと考觉られた。すなわち, IPAの投与は, ADHによるアセトンへの酸化過程によって細胞内にNADH を增加させ，NADHの存在下において進行するCHから TCE への反応を促進し，NADHを産生するCHから TCAへの 反応を抑制したものと考えられた(図5B)。

しかしながら，TCAとTCEの合計産生率はIPA共存下 においても影響を受けなかった。これは，Kawamoto

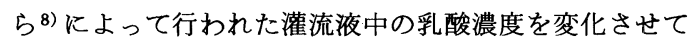
得られた細胞内酸化還元状態の変化に応じたTCA/TCE 比の変化に関する観察濃度と相応する結果と考兄られた。 また, 本実験条件下では, IPAの代謝はCHの共存下に
A

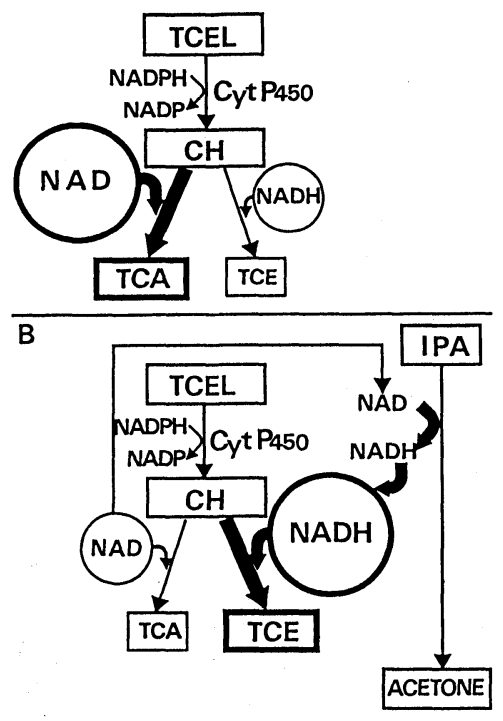

Fig. 5 Changes in the pool size of NADH and metabolic pathways of trichloroethylene (TCEL) and isopropyl alcohol (IPA) in the rat liver cell

$A$ : TCEL is metabolized to $\mathrm{CH}$ by the cytochrome $\mathrm{P}_{450}$ system, and then metabolized to TCA and TCE. The production rate of TCA is greater than that of TCE due to the intracellular NAD/NADH ratio.

$B$ : The production rate of TCE is increased compared to TCA by the coexistence of the isopropyl alcohol (IPA), where NADH is produced by the oxidation of isopropyl alcohol. The change in size of the NADH pool is considered to cause conversion of the ratio of TCEL metabolites.

おいて抑制される事実が得られた。Sellersら ${ }^{16)}$ は， CH が领酒による酪酎状態を強めるといら現象に注目し， $\mathrm{CH}$ がエタノールからアセトアルデヒドの代謝を抑制するこ とを報告している。さらに, Sellersらは, CHのェタノー ル酸化抑制機序が，CHの代謝産物であるTCEによるADH 代謝阻害作用によるものであることを報告している。IPA が，同じくADHにより酸化され，アセトンに変換され ることを考劣るならば，本実験結果におけるCHのIPA 代謝抑制機序も，主として，TCEによるADH阻害作用 によるものと思われた。しかしながら, 本実駼結果から は，その断定をすることができない。

以上より, IPAがTCEL代謝に影響を与え, また, TCEL の中間代謝産物のCHがなんらかの機序によって, IPA 代謝に影響を与えることが示唆された。 


\author{
結語 \\ ラットの灌流肝臓を実験モデルとして，TCELとIPA \\ の代謝における相互作用を検討した。その結果, IPAは \\ 細胞内NADHレベルを高めることにより，TCELの代謝 \\ 産物比(TCA/TCE比)を变化させ，またTCELはIPAのア \\ セトンへの代謝を抑制することが判明した。
}

本研究は文部省科学研究費(課題番号05454224)の補助 を受けた。

\section{文献}

1) Sittig, M.: Handbook of Toxic and Hazardous Chemicals, pp. 672-675, Noys Publications, Park Ridge, New Jersey (1981).

2 ) World Health Organization: Environmental Health Criteria 50. Trichloroethylene, World Health Organization, Geneve (1985).

3 ) Sittig, M.: Handbook of Toxic and Hazardous Chemicals, pp. 397-399, Noys Publications, Park Ridge, New Jersey (1981).

4 ) Waters, E.M., Gerstner, H.B. and Huff, J.E.: Trichloroethylene. I. An overview, J. Toxicol. Environ. Health , 2, 671-707 (1977).

5 ) Ikeda, M., Miyake, Y., Ogata, M. and Ohmori, S. : Metabolism of trichloroethylene, Biochem. Pharmacol. , 29, 2983-2992 (1980).

6) Shultz, J. and Weiner, H.: Alteration of the enzymology of chloral hydrate reduction in the presence of ethanol, Biochem. Pharmacol., 28, 3379-3384 (1979).

7) Kimbrough, R.D., Mitchell, F.L. and Houk, V.N.: Trichloroethylene: an update, J. Toxicol. Environ. Health, 15, 369-383 (1985).

$8)$ Kawamoto, T., Hobara, T., Kobayashi, H., Iwamoto, S., Sakai, T., Takano, T. and Miyazaki, Y.: The metabolite ratio as a function of chloral hydrate dose and intracellular redox state in the perfused rat liver, Pharmacol. Toxicol., 60, 325-329 (1987).
9) Abshagen, U. and Rietbrock, N.: Zum mechanismus der 2-propanoloxydation. Interferenzversuche mit niederen aliphatischen alkoholen in vivo und an der isoliert perfundierten rattenleber, Naunyn Schmiedebergs Arch. Pharmacol., 265, 411-424 (1970).

10) Nordmann, R., Ribiere, C., Rouach, H., Beauge, F. , Giudicelli, Y. and Nordmann, J.: Metabolic pathways involved in the oxidation of isopropanol into acetone by the intact rat, Life Sci. , 13, 919-932 (1973).

11) Takano, T., Miyazaki, Y. and Motohashi, Y.: Interaction of trichloroethane isomers with cytochrome P-450 in the perfused rat liver, Fundam. Appl. Toxicol. , 5, 353-360 (1985).

12）高野健人, 宮崎良文, 本橋 豊: ラット灌流肝臟を もちいた環境中化学物質による細胞内代謝動態変化 の観察方法一灌流肝臓における呼吸鎖チトクローム 類, チトクローム $\mathrm{P}_{450}$, カタラーゼの可視域スペク トル変化, および還元型ピリジンヌクレオチドの蛍 光变化の経時的同時測定, 日衛誌，38, 649-656 (1983).

13) Humbert, B.E. and Fernandez, J.G.: Simultaneous determination of trichloroacetic acid and trichloroethanol by gas chromatography, Int. Arch. Occup. Environ. Health, 36, 235-241 (1976).

14）日本薬学会：衛生試験法-注解，pp. 1097-1098, 金原出版, 東京 (1980).

15) Bucher, T., Brauser, B., Conze, A., Klein, F., Langguth, O. and Sies, H.: State of oxidation-reduction and state of binding in the cytosolic NADH-system as disclosed by equilibration with extracellular lactate/pyruvate in hemoglobin-free perfused rat liver, Eur. J. Biochem., 27, 301-317 (1972).

16) Sellers, E.M., Lang, M. , Koch-Weser, J., LeBlanc, E. and Kalant, H.: Interaction of chloral hydrate and ethanol in man. I. Metabolism, Clin. Pharmacol. Ther., 13, 37-49 (1972).

（受付 1993 年 7 月 13 日 受理 1993 年 9 月 27 日） 